\title{
PENINGKATAN PROFESIONALISME GURU AL-QUR'AN SEKOLAH DASAR ISLAM TERPADU
}

\author{
Syaefulloh Saiful Nawawi ${ }^{1}$, Nanat Fatah Nasir ${ }^{2}$, Muhibbin Syah ${ }^{3}$, Qiqi Yuliati Zaqiah ${ }^{4}$ \\ 1,2,3,4 UIN Sunan Gunung Djati Bandung \\ ${ }^{1}$ saifulnawawi12@gmail.com
}

\begin{abstract}
Integrated Islamic Primary Schools Al-Izzah and Al-Hanif are schools that make the Al-Qur'an program their flagship program. In the application process, there are obstacles in the aspect of teacher professionalism. On that basis, the institution made efforts to increase the professionalism of Al-Qur'an teachers. This study aims to identify Al-Qur'an teachers' professionalism and efforts to increase the professionalism of teachers at SDIT Al-Izzah Serang and SDIT Al-Hanif Cilegon as many as 50 people. This research uses a qualitative approach with a descriptive analysis method. Data collection techniques through observation, interviews, and documentation study. Data analysis was performed by reducing data, displaying, verifying, presenting, and drawing conclusions. The results of the research show that the professionalism of Al-Qur'an teachers at SDIT Al-Izzah and Al-Hanif is good in the aspects of basic education science, preparation of learning programs, implementation of teaching programs, assessment of results and teaching and learning processes, school administration, services and counseling, selfconcept, good self-esteem, teachers 'beliefs about the effectiveness of their own abilities in arousing students' passion and acceptance of themselves and others, good personality and teacher welfare. Meanwhile, the Al-Qur'an SDIT Al-Izzah teacher professionalism improvement program is izzati coaching, tahsin coaching, simaan, teacher certification, mukhoyyam Al-Qur'an, supervision, teacher working groups, comparative studies, seminars, and Islamic personal development. Meanwhile, the Al-Qur'an SDIT Al-Hanif teacher professionalism improvement program is tashih, tahsin, teacher certification, coach, supervision, recitation guidance, coordinator guidance, seminars, and Tuesday afternoon studies.
\end{abstract}

Keywords: professionalism; teacher of Al-qur'an

\begin{abstract}
Abstrak
Sekolah Dasar Islam Terpadu Al-Izzah dan Al-Hanif merupakan sekolah yang menjadikan program Al-Qur'an sebagai program unggulan. Dalam proses penerapannya menemukan kendala dalam aspek profesionalisme guru. Atas dasar itu, lembaga melakukan upaya peningkatan profesionalisme guru AlQur'an. Penelitian ini bertujuan untuk mengidentifikasi profesionalisme guru Al-Qur'an, dan upaya peningkatan profesionalisme guru di SDIT Al-Izzah Serang dan SDIT Al-Hanif Cilegon sebanyak 50 orang. Penelitian ini menggunakan pendekatan kualititaf dengan metode deskriptif analisis. Teknik pengumpulan data melalui observasi, wawancara, dan studi dokumentasi. Analisis data dilakukan dengan cara mereduksi data, men-display, verifikasi, memaparkan dan mengambil simpulan. Hasil peneletian menunjukkan bahwa profesionalisme guru Al-Qur'an di SDIT Al-Izzah dan Al-Hanif sudah baik dalam aspek landasan ilmu kependidikan, penyusunan program pembelajaran, pelaksanaan program pengajaran, penilaian hasil dan proses belajar mengajar, administrasi sekolah, layanan dan bimbingan konseling, self-concept, self-esteem yang baik, keyakinan guru terhadap kefektifan kemampuannya sendiri dalam membangkitkan gairah siswa dan sikap penerimaan terhadap diri sendiri dan orang lain, berkepribadian baik dan kesejahteraan guru. Sementara itu, Program peningkatan profesionalisme guru Al-Qur'an SDIT Al-Izzah adalah pembinaan izzati, pembinaan tahsin, simaan, sertifikasi guru, mukhoyyam Al-Qur'an, supervisi, kelompok kerja guru, studi banding, seminar dan bina pribadi Islami. Sementara itu, program peningkatan profesionalisme guru Al-Qur'an SDIT Al-Hanif adalah tashih, tahsin, sertifikasi guru, coach, supervisi, pembinaan tilawah, pembinaan koordinator, seminar dan kajian selasa siang.
\end{abstract}

Kata Kunci: guru Al-qur'an; profesionalisme

\begin{tabular}{llll} 
Received & $: 2021-04-14$ & Approved & $: 2021-05-06$ \\
Reviesed & $: 2021-05-03$ & Published & $: 2021-07-31$ \\
\hline
\end{tabular}


Jurnal Cakrawala Pendas is licensed under a Creative Commons AttributionShareAlike 4.0 International License.

\section{Pendahuluan}

Sekolah Dasar Islam Terpadu merupakan salah satu sekolah Islam tingkat dasar yang banyak diminati oleh masyarakat. Salah satu alasannya adalah karena Sekolah Dasar Islam Terpadu memiliki program unggulan tahsin dan tahfizh Al-Qur'an. Program tahsin dan tahfizh AlQur'an menjadi salah satu tujuan dan harapan orangtua ketika menitipkan putra putrinya di sekolah berbasis Islam, Sekolah Dasar Islam Terpadu di antaranya. Hal itu dapat dilihat dari banyaknya orangtua siswa yang mendafarkan putra putrinya di Sekolah Dasar Islam Terpadu meskipun secara biaya tergolong cukup mahal. Namun demikian, harapan orangtua yang menitipkan putra putrinya di Sekolah Dasar Islam Terpadu masih banyak yang belum terwujudkan karena masih cukup banyak terdapat lembaga yang belum bisa membuktikan hasilnya. Hal itu terlihat dari belum tercapainya target yang ditetapkan baik dalam aspek capaian hafalan siswa siswi (tahfizh), maupun dalam aspek kemampuan membaca Al-Qur'an (tahsin).

Lebih lanjut dikatakan bahwa, Guru memiliki banyak tugas, baik yang terikat oleh dinas maupun di luar dinas dalam bentuk pengabdian. Dapat dipahami bahwa ada tiga jenis tugas guru, yakni tugas dalam bidang profesi, tugas kemanusiaan, dan tugas dalam bidang kemasyarakatan (Fathurrahman, 2018), (Sudiati, 2018), (Rumapea, 2005). Selanjutnya, Guru merupakan profesi atau jabatan yang memerlukan keahlian khusus. Jenis pekerjaan ini tidak dapat dilakukan oleh sembarang orang di luar bidang kependidikan, walaupun kenyataannya masih ada yang dilakukan oleh orang di luar kependidikan. Dapat dipahami bahwa, tugas guru sebagai profesi meliputi mendidik, mengajar dan melatih. Mendidik berarti meneruskan dan mengembangkan nilai-nilai hidup (Musyadad, 2020), (Lukman \& Ramli, 2016), (Lubis, 2017). Mengajar berarti meneruskan, mengembangkan ilmu pengetahuan dan tekhnologi. Sedangkan melatih berarti mengembangkan ketrampilan-ketrampilan pada siswa.

Selanjutnya, Nasution (2017); Rahman (2013) mengemukakan bahwa Guru adalah salah satu di antara faktor pendidikan yang memiliki peranan yang paling strategis, sebab gurulah sebetulnya yang paling menentukan di dalam terjadinya proses belajar mengajar. Peran guru sangat vital bagi pembentukan kepribadian, cita-cita, dan visi misi yang menjadi impian hidup anak didiknya di masa depan. Lebih lanjut, Amrulah (2005) mengemukakan bahwa di balik kesuksesan murid, selalu ada guru profesional yang memberikan inspirasi dan motivasi besar pada dirinya sebagai sumber stamina dan energi untuk selalu belajar dan bergerak mengejar ketertinggalan, menggapai kemajuan, menorehkan prestasi spektakuler dalam mencapai kemajuan suatu bangsa.

Noorjannah (2014) mengatakan bahwa profesional adalah pekerjaan atau kegiatan yang dilakukan oleh seseorang dan menjadi sumber penghasilan kehidupan yang memerlukan kehlian atau kecakapan yang memenuhi mutu atau norma tertentu serta memerlukan pendidikan profesi. Selanjutnya, Rusman (2012) menyebutkan bahwa profesional menunjuk pada dua hal yaitu: 1) orang yang melakukan pekerjaan dan menyandang suatu profesi, misalnya "dia seorang yang profesioanal", dan 2) penampilan seseorang dalam melakukan pekerjaannya yang sesuai dengan profesinya atau kinerja orang tersebut. Dalam pengertian kedua ini pengertian profesional di kontraskan dengan dengan non profesioanal atau amatiran. Dalam kegiatan sehari-hari seorang profesional melakukan pekerjaan sesuai dengan bidang ilmu yang dimilikinya, jadi tidak asal-asalan. Dapat dipahami bahwa, profesionalisme merujuk pada komitmen anggota-anggota suatu profesi untuk meningkatkan kemampuan profesionalnya dan terus-menerus mengembangkan strategi yang digunakanya dalam melakukan pekerjaan yang sesuai dengan profesinya. Selanjutnya (Kunandar, 2007),(Baharun, 2016),(Anggoro et al., 2018), (Sholihah, 2018) menyatakan bahwa profesionalisme merupakan kondisi, arah, nilai, tujuan dan kualitas suatu keahlian dan kewenangan yang berkaitan dengan mata pencaharian seseorang.

Rusman (2012) mengatakan bahwa profesionalisme guru merupakan kondisi, arah, nilai, dan kualitas suatu keahlian dan kewenangan dalam bidang pendidikan dan pembelajaran 
yang berkaitan dengan pekerjaan seseorang yang menjadi mata pencaharian. Sementara itu, guru yang profesional adalah guru yang memiliki kompetensi yang dipersyaratkan untuk melakukan tugas pendidikan dan pembelajaran. Dengan kata lain, dapat disimpulkan bahwa pengertian guru profesional adalah orang yang memiliki kemampuan dan keahlian khusus dalam bidang keguruan, sehingga ia mampu melakukan tugas dan fungsinya sebagai guru dengan kemampuan maksimal. Guru yang profesional adalah orang yang terdidik dan terlatih dengan baik, serta memiliki pengalaman yang luas dibidangnya (Salmiati \& Septiawansyah, 2019). Sedangkan (Hamalik, 2006), (Darmadi, 2015) mengemukakan bahwa guru profesional merupakan orang yang telah menempuh pendidikan guru dan memiliki tingkat master serta telah mendapat ijazah negara dan telah berpengalaman dalam mengajar pada kelas-kelas besar.

Dapat dipahami bahwa upaya yang dapat dilaksanakan untuk meningkatkan profesionalisme guru antara lain: 1) menerima kehadiran guru dengan baik; 2) memberi tugas mengajar baru sesuai dengan bidang dan kompetensi yang dikuasi oleh guru; 3) membentuk dan melaksanakan kelompok kerja guru bidang studi dan musyawarah guru bidang studi sejenis (MGMP) sebagai wadah bagi guru untuk berdiskusi merencanakan masalah dan memecahkan masalah yang terjadi di kelas; 4) melakukan supervisi administrasi dan akedemik terhadap guru sebagai bahan perbaikan dan menentukan kebijakan; 5) melakukan pembinaan baik bersifat administratif, akademik, maupun karier guru; 6) memberi kesempatan pada guru untuk mengikuti pelatihan baik yang dilaksanakan di sekolah, kabupaten, propinsi maupun pada tingkat nasional; 7) memberi reward (penghargaan) pada guru yang berprestasidan memberikan hukuman pada guru yang malas dan bermasalah; 8) memberi tugas tambahan pada guru; 9) membentuk ikatan keluarga di sekolah masing-masing dengan pertemuan dilaksanakan di rumah anggota ikatan keluarga (Mania, 2008), (Zubair, 2017).

Berdasarkan hasil studi pendahuluan yang dilakukan oleh peneliti menunjukkan bahwa penyebab tidak tercapainya target dan tujuan tersebut antara lain; a) lemahnya kemampuan guru Al-Qur'an dalam aspek kemampuan membaca dan hafalan Al-Qur'an (tahsin dan tahfizh), b) terdapat banyak guru yang belum strata satu (S1), c) rasio guru dan siswa belum proporsional, d) guru Al-Qur'an merangkap dengan mata pelajaran lain, e) penguasaan guru terhadap kelas, anak-anak dan metodologi pembelajaran yang masih lemah, f) kedisiplinan dan loyalitas guru dalam mengajar, dan g) guru yang tidak membuat RPP dan laporan harian.

Jika masalah-masalah ini terjadi secara terus menerus, akan mempengaruhi profesionalisme guru itu sendiri yang akan menjadi semakin lemah dan menurun serta memberi dampak negatif terhadap mutu pembelajaran Al-Qur'an. Berdasarkan pemaparan di atas, peneliti perlu melakukan kajian secara ilmiah mengenai Peningkatan Profesionalisme Guru AlQur'an Sekolah Dasar Islam Terpadu.

\section{Metode Penelitian}

Penelitian ini menggunakan pendekatan kualitatif. Peneliti terjun langsung ke lapangan untuk mengumpulkan data. Metode yang digunakan adalah deskriptif kualitatif. Teknik pengumpulan data melalui observasi, wawancara, kuesioner dan dokumentasi. Observasi dilakukan dengan melihat langsung program peningkatan profesionalisme guru Al-Qur'an. Wawancara dilakukan dengan pengawas yayasan, ketua yayasan, kepala sekolah, wakil kepala sekolah, koordinator Al-Qur'an dan para guru Al-Qur'an untuk menggali informasi tentang profesionalisme guru, program dan pelaksanaan program peningkatan profesionalisme guru AlQur'an. Kuesioner digunakan untuk mengumpulkan data tentang profesionalisme guru yang diambil langsung dari guru Al-Qur'an. Adapun dokumentasi dilakukan dengan melihat dokumen-dokumen penting yang mendukung penelitian.

Teknis analisis data dilakukan dengan cara menyusun data secara sistematis yang diperoleh dari hasil observasi, wawancara, kuesiner dan dokumentasi dengan cara mengorganisasikan data ke dalam kategori, menjabarkan ke dalam unit-unit, melakukan sintesa, menyusun ke dalam pola, memilih mana yang penting dan akan dipelajari dan membuat simpulan sehingga mudah dipahami oleh diri sendiri dan orang lain. 
Langkah-langkah yang ditempuh dalam analisis data tersebut menggunakan teori yang diungkapkan oleh (Nasution, 2003) yaitu melalui: 1) mereduksi data, 2) men-display data, 3) mengambil simpulan dan verikasi, 4) menganalisis data, 5) membuat lembaran rangkuman, dan 6) menggunakan matriks dalam analisis data.

Penelitian dilakukan sejak bulan Oktober 2020 sampai dengan Februari 2021 di SDIT Al-Izzah Serang yang berlamatkan di J1. Tb Husni Qodir, Pabuaran Baru Kelurahan Unyur Kecamatan Serang Kota Serang Banten, dan SDIT Al-Hanif yang beralamatkan di Jalan Perumnas Bumi Cibeber Kencana (BCK) Kelurahan Karang Asem Kecamatan Cibeber Kota Cilegon Banten. Sasaran penelitian adalah para pengurus yayasan yang terdiri dari pengawas dan ketua yayasan serta pengelola sekolah yang terdiri dari kepala sekolah, wakil kepala sekolah, koordinator Al-Qur'an, guru Al-Qur'an dan semua yang terlibat dalam program peningkatan profesionalisme guru pada kedua lembaga tersebut dengan jumlah 50 orang.

\section{Hasil dan Pembahasan}

Profesionalisme guru Al-Qur'an SDIT Al-Izzah memenuhi sebagian besar indikator profesionalisme guru. Indikator profesionalisme guru yang terpenuhi pada lembaga ini terletak pada penguasaan landasan ilmu kependidikan, menyusun program pembelajaran, melaksanakan program pengajaran, menilai hasil dan proses belajar mengajar, menyelenggarakan administrasi sekolah, mengenal fungsi layanan dan bimbingan konseling, persepsi terhadap dirinya sendiri (self-concept) dan penilaian guru terhadap diri berdasarkan prestasi (self-esteem) yang baik, keyakinan guru terhadap kefektifan kemampuannya sendiri dalam membangkitkan gairah siswa, sikap penerimaan terhadap diri sendiri dan orang lain, berkepribadian baik dan kesejahteraan guru. Sementara itu, aspek indikator yang masih kurang terletak pada penguasaan bahan pengajaran yang mencakup penguasaan teori makharijul huruf, penguasaan teori sifatul huruf, praktek makharijul huruf dan sifatul huruf, penguasaan materi dan pokok bahasan buku yang diajarkan, penguasaan teori dan praktek ghoroibul qur'an, dan penguasaan materi dan praktek tajwid dasar, dan kecakapan membaca dan berbicara yang mencakup tartil membaca Al-Qur'an dan mampu melaksanakan tahapan pembelajaran dengan baik (membuka, mengulang pelajaran, menjelaskan materi baru, mencoba dan melatih materi baru).

Adapun profesionalisme guru SDIT Al-Hanif juga sudah cukup baik karena telah terpenuhinya sebagian besar indikator profesionalisme guru. Indikator profesionalisme guru yang terpenuhi di lembaga ini terletak pada penguasaan materi dan pokok bahasan buku yang diajarkan, melaksanakan program pengajaran, mampu melaksanakan tahapan pembelajaran dengan baik, menilai hasil dan proses belajar mengajar, penguasaan teori dan praktek ghoroibul qur'an, dan penguasaan materi dan praktek tajwid dasar, menyelenggarakan administrasi sekolah, pada penguasaan bahan pengajaran, mengenal fungsi layanan dan bimbingan konseling, persepsi terhadap dirinya sendiri (self-concept) dan penilaian guru terhadap diri berdasarkan prestasi (self-esteem) yang baik, keyakinan guru terhadap kefektifan kemampuannya sendiri dalam membangkitkan gairah siswa, sikap penerimaan terhadap diri sendiri dan orang lain, berkepribadian baik dan kesejahteraan guru. Sementara itu, aspek indikator yang masih kurang terletak penguasaan landasan ilmu kependidikan, menyusun program pembelajaran, kecakapan membaca dan berbicara yang mencakup tartil membaca Al-Qur'an, penguasaan teori makharijul huruf, penguasaan teori sifatul huruf, praktek makharijul huruf dan sifatul huruf. Selain masih banyak guru yang belum menempuh atau menyelasokan program pendidikan strata satu (S1).

Disiplin ilmu kependidikan ini terdiri dari dua macam, yaitu: pengetahuan kependidikan umum dan pengetahuan kependidikan khusus. Pengetahuan kependidikan umum meliputi: ilmu pendidikan, psikologi pendidikan, administrasi pendidikan dan seterusnya. Sementara itu, pengetahuan kependidikan khusus meliputi : metode mengajar, metodik khusus pengajaran materi tertentu, teknik evaluasi, praktik keguruan dan sebagainya. Dengan kata lain, pengetahuan/ilmu pendidikan umum itu meliputi segenap pengetahuan kependidikan yang tidak langsung berhubungan dengan proses mengajar belajar, sedangkan ilmu pendidikan khusus langsung dengan praktik pengeloaan proses mengajar belajar (PMB). 
Penguasaan terhadap pemahaman tentang makharijul huruf dan sifatul huruf beserta cara pengucapannnya merupakan hal yang penting sekaligus merupakan pondasi dan pilar bacaan Al-Qur'an. Jika seseorang telah menguasai makhraj dan sifat huruf maka bacaan Al-Qur'annya akan menjadi baik, benar dan indah. Terlebih bagi seorang guru yang mengajarkan Al-Qur'an, wajib hukumnya menguasai teori dan praktek tentang makharijul huruf dan sifatul huruf.

Masruri (2016) menyebutkan bahwa salah satu materi yang akan dipelajari oleh siswa pada saat mempelajari Al-Qur'an adalah materi bacaan asing atau yang disebut dengan ghoroibul qur'an, yaitu bacaan yang berbeda dari kaidah dasar cara membaca Al-Qur'an. Selain materi ghorib, siswa akan mempelajari hukum bacaan Al-Qur'an yang disebut dengan ilmu tajwid. Oleh karena itu, guru diharuskan memahami dan menguasai materi ilmu ghoroibul qur'an dan ilmu Tajwid, sehingga guru akan terhindar dari kesalahan pada saat mengajar Al-Qur'an. Ia juga menambahkan bahwa standar pertama yang harus dimiliki oleh guru Al-Qur'an adalah tartil membaca Al-Qur'an. Yang dimaksud dengan tartil membaca Al-Qur'an adalah mampu membaca Al-Qur'an dengan benar dan baik, mampu mengucapkan huruf dengan tepat sesuai makharijul huruf, dan mengetahui waqaf ibtida yang baik dan sesuai dengan makna. Dengan kata lain guru yang mengajar Al-Qur'an harus di pastikan bacaan Al-Qur'annya baik dan tartil sesuai dengan kaidah ilmu tajwid.

Guru yang profesional memerlukan self-concept yang tinggi. Guru demikian dalam mengajarnya akan lebih cenderung memberi peluang luas kepada para siswa untuk berkreasi dibanding dengan guru yang ber self-concept rendah (negatif). Guru yang ber-self-concept rendah biasanya lebih banyak "berkicau" sehingga tidak sempat memberi peluang kepada siswa untuk berkreasi seperti bertanya atau menyampaikan pendapat. Akibatnya, para siswa menjadi "masyarakat bisu".

Guru yang memiliki konsep-diri yang tinggi umumnya memiliki harga diri yang tinggi pula. la mempunyai keberanian mengajak dan mendorong serta membantu dengan sekuat tenaga kepada para siswanya agar lebih maju. Fenomena keberanian mengajak dan mendorong para siswa supaya maju itu didasari oleh keyakinan guru tersebut terhadap kualitas prestasi akademik yang telah ia miliki. Oleh karena itu, untuk memiliki konsep-diri yang positif, para guru perlu berusaha mencapai prestasi akademik setinggi-tingginya dengan cara banyak belajar dan terus mengikuti perkembangan zaman.

Self-efficacy guru (efikasi guru), lazim juga disebut personal teacher efficacy, adalah keyakinan guru terhadap keefektifan kemampuannya sendiri dalam membangkitkan gairah dan kegiatan para siswanya. Kompetensi ranah rasa ini berhubungan dengan kompetensi ranah rasa lainnya yang disebut teaching efficacy atau contextual efficacy yang berarti kemampuan guru dalam berurusan dengan keterbatasan faktor di luar dirinya ketika ia mengajar. Artinya, keyakinan guru terhadap kemampuannya sebagai pengajar profesional bukan hanya dalam hal menyajikan materi pelajaran di depan kelas saja, melainkan juga dalam memanipulasi (mendayagunakan) keterbatasan ruang, waktu dan peralatan yang berhubungan dengan proses mengajar-belajar.

Sikap penerimaan terhadap diri sendiri (self-acceptance attitude) adalah gejala ranah rasa seorang guru dalam berkecenderungan positif atau negatif terhadap dirinya sendiri berdasarkan penilaian yang lugas atas bakat dan kemampuannya. Sikap penerimaan terhadap diri sendiri ini diiringi dengan rasa puas terhadap kelebihan dan kekurangan yang ada pada diri guru tersebut. Sikap seperti ini kurang lebih sama dengan sikap qana'ah dalam pendidikan akhlak. Sikap qana'ah terhadap kemampuan yang ada pada dirinya sendiri pada umumnya berpengaruh secara psikologis terhadap sikap penerimaan pada orang lain (others acceptance attitude). Sebagai pemberi layanan kepada siswa (sebagai pembantu dan pembimbing serta anutan kegiatan belajar siswa), guru seyogianya memiliki sikap positif terhadap dirinya sendiri. Alasannya, kompetensi bersikap seperti ini akan cukup berpengaruh terhadap tinggi rendahnya kualitasdan kuantitas layanan kepada siswa.

Berdasarkan keterangan di atas, secara umum profesionalisme guru di kedua lembaga tempat penelitian ini dapat dikatakan cukup baik karena terpenuhinya indikator-indikator profesionalisme guru. Meski demikian, indikator-indikator yang terpenuhi jika diamati secara 
teliti dan mendalam, akan didapati bahwa indikator-indikator tersebut masih termasuk indikator umum profesionalisme guru, belum masuk ke ranah indikator utama profesionalisme guru Al-Qur'an. Artinya, dalam profesionalisme guru Al-Qur'an terdapat indikator umum dan khusus. Indikator khusus berkaitan erat dengan pilar bacaan yaitu makhraj dan sifat huruf, pada indikator ini profesionalisme guru masih belum kuat.

Erwiyanto (2019) menyatakan bahwa bacaan Al-Qur'an seseorang akan dipengaruhi oleh tiga pilar bacaan Al-Qur'an yaitu makharijul huruf, sifatul huruf dan harokat. Jika pemahaman, penguasaan dan kemampuan seseorang terhadap tiga pilar tersebut baik, maka bacaan Al-Qur'annya juga menjadi baik. Apabila dikaitkan dengan mutu pembelajaran AlQur'an dan program peningkatan profesionalisme guru, maka pembelajaran Al-Qur'an dan program peningkatan profesionalisme guru yang bermutu adalah pembelajaran dan program peningkatan profesionalisme guru yang menitikberatkan peserta didik dan gurunya untuk memahami, menguasai dan mampu mempraktekkan tiga pilar bacaan Al-Qur'an tersebut yaitu: makharijul huruf, sifatul huruf dan harokat.

Program peningkatan profesionalisme guru Al-Qur'an SDIT Al-Izzah Kota Serang dan SDIT Al-Hanif Cilegon jika dilihat dari aspek inisiasi program menunjukan bahwa semua program yang dijalankan oleh SDIT Al-Izzah dan SDIT Al-Hanif apabila diklasifikasikan maka termasuk kategori program Top-Down Model, yaitu program yang ide dasarnya dari atas ke bawah, atau dengan arti lain termasuk kategori program yang inisiasinya dari pimpinan atau atasan. Adapun Program peningkatan profesionalisme guru Al-Qur'an SDIT Al-Izzah adalah pembinaan izzati, pembinaan tahsin, simaan, sertifikasi guru, mukhoyyam Al-Qur'an, supervisi, kelompok kerja guru, studi banding, seminar dan bina pribadi Islami. Sementara itu, program peningkatan profesionalisme guru Al-Qur'an SDIT Al-Hanif adalah tashih, tahsin, sertifikasi guru, coach, supervisi, pembinaan tilawah, pembinaan koordinator, seminar dan kajian selasa siang.

Dari sepuluh program yang dilaksanakan di SDIT Al-Izzah terdapat beberapa program yang berkaitan langsung dengan peningkatan profesionalisme guru Al-Qur'an dan terdapat pula program yang tidak berkaitan langsung peningkatan profesionalisme guru Al-Qur'an. Adapun program yang berkaitan langsung dengan peningkatan profesionalisme guru Al-Qur'an adalah program pembinaan izzati, pembinaan tahsin tahfizh unit, simaan murojaah, sertifikasi guru dan wisuda tahfizh, mukhoyyam Al-Qur'an, seminar dan pelatihan, supervisi dan kelompok kerja guru. Sementara program yang tidak berkaitan langsung adalah program studi banding dan bina pribadi islami (BPI)

Pada program yang selenggarakan oleh SDIT Al-Izzah dan berkaitan langsung dengan peningkatan profesionalisme guru Al-Qur'an terdapat program inti yang tujuan dan kegiatan sama yaitu program pembinaan izzati, pembinaan tahsin tahfizh unit dan simaan murojaah. Adapun program lainnya merupakan program pendukung yaitu sertifikasi guru dan wisuda tahfizh, mukhoyyam Al-Qur'an, seminar dan pelatihan, supervisi dan kelompok kerja guru. Sementara itu, program yang tidak berkaitan langsung dengan peningkatan profesionalisme guru juga merupakan program pendukung.

Tiga program inti pembinaan izzati, pembinaan tahsin tahfizh unit dan simaan murojaah, menekankan pada penguatan dalam aspek hafalan dan bacaan. Ketiga program tersebut memiliki tujuan yang sama yaitu meningkatan profesionalisme guru dalam aspek penguasaan bahan pengajaran dan kecakapan membaca dan berbicara melalui bacaan, hafalan dan metodologi. Secara spesifik ketiga program ini lebih fokus menekankan kepada peningkatan kemampuan guru dalam aspek bacaan, hafalan dan metodologi pengajaran.

Berdasarkan pada temuan hasil penelitian menunjukkan permasalahan utama profesionalisme guru Al-Qur'an di SDIT Al-Izzah terletak pada lemahnya guru dalam penguasaan bahan pengajaran dan kecakapan membaca dan berbicara yang diukur dari kemampuan membaca dan menghafal Al-Qur'an serta metodologi. Upaya yang dilakukan lembaga untuk meningkatkan profesionalisme guru Al-Qur'an melalui program pembinaan izzati, tahsin tahfizh unit dan simaan murojaah sudah tepat dan benar, akan tetapi pelaksanaan program ini lebih banyak menekankan pada aspek peningkatan jumlah hafalan saja. Seharusnya penekanan program ini pada aspek masalah terbesar yaitu pada bacaan guru yang masih lemah 
dan perlu ditingkatkan agar tepat sasaran. Oleh karena itu, ketiga program ini dipandang belum optimal dan spesifik dalam meningkatkan profesionalisme guru.

Pada program yang berkaitan langsung dengan peningkatan profesionalisme guru, terdapat program yang memberi dampak positif akan tetapi dampak positif tersebut lebih kepada motivasi, pemahaman, memunculkan ide dan inovasi dalam pembelajaran, sementara permasalahan utama di SDIT Al-Izzah aspek bacaan guru dan metodologi, sehingga program ini diniliai kurang efektif dan efisien seperti program sertifikasi guru dan wisuda tahfizh, mukhoyyam Al-Qur'an, seminar dan pelatihan, studi banding.

Program sertifikasi (wisuda tahfizh guru) lebih menekankan pada motivasi menambah hafalan dan semangat menghafal dengan pemberian reward atau penghargaan dalam bentuk pemberian insentif oleh pihak lembaga kepada guru yang mengikuti wisuda. Adapun program mukhoyyam Al-Qur'an dinilai belum tepat sasaran, karena salah satu kekurangan guru bacaan Al-Qur'an guru yang belum tartil. Sehingga upaya yang seharusnya dilakukan adalah meningkatkan profesionalisme dalam aspek penguasaan bahan pengajaran Al-Qur'an yang tartil terlebih dahulu, bukan hanya fokus mengejar target hafalan yang rata-rata guru sudah cukup jumlah hafalannya, Mulyasa menyebutkan bahwa upaya peningkatan kualitas profesionalisme guru harus didasarkan kepada kelemahan-kelemahan yang dihadapi oleh guru.

Program supervisi dan kelompok kerja guru (KKG) merupakan program yang dinilai baik, tepat sasaran, dan diperlukan oleh guru, sesuai dengan kondisi dan kebutuhan guru khususnya dalam aspek metodologi pengajaran. Zubair (2017) menyebutkan bahwa upaya yang dapat dilaksanakan untuk meningkatkan profesionalisme dan kinerja guru antara lain: melakukan supervisi administrasi dan akedemik terhadap guru sebagai bahan perbaikan dan menentukan kebijakan, melakukan pembinaan baik bersifat administratif, akademik, maupun karier guru,

Adapun program bina pribadi islami dan studi banding merupakan program yang tidak berkaitan langsung dengan peningkatan profesioanalisme guru di SDIT Al-Izzah. Program ini lebih menekankan pada aspek spiritual melalui pembinaan pekanan yang dilakukan oleh masing-masing wali kelas kepada guru binaan. Secara umum program ini dinilai bagus dan perlu untuk dilaksanakan, khususnya peningkatan aspek spiritual dan pemahaman keagamaan. Akan tetapi, jika dilihat dari kesesuaian program ini dengan kondisi guru, maka program ini dinilai belum tepat sasaran, karena kelemahan kekurangan guru bacaan Al-Qur'an guru yang belum tartil. Sehingga upaya yang seharusnya dilakukan adalah fokus dan menitikberatkan pada peningkatan profesionalisme dalam aspek penguasaan bahan pengajaran yaitu bacaan AlQur'an yang tartil. Hal ini sesuai dengan pandangan Mulyasa yang menyebutkan bahwa upaya peningkatan kualitas profesionalisme guru harus didasarkan kepada kelemahan-kelemahan yang dihadapi oleh guru.

Berdasarkan keterangan di atas, disimpulkan bahwa program peningkatan profesionalisme guru yang diselenggarakan di SDIT Al-Izzah Serang terdapat program yang berkaitan langsung dengan kondisi, kebutuhan dan profesionalisme guru dan terdapat pula program yang tidak berkaitan langsung dengan kondisi, kebutuhan dan profesionalisme guru. Dari program yang berkaitan dengan kondisi, kebutuhan dan profesionalisme terdapat program yang optimal dan program yang belum optimal. Sementara program yang tidak berkaitan langsung memberi manafaat dan dampak positif namun tidak berkaitan langsung dengan kebutuhan utama profesionalisme guru.

Hal ini dikarenakan dalam membuat program lembaga belum menerapkan standar perencanaan, model pelaksanaan program dan evaluasi yang akan digunakan dalam program tersebut, sehingga program yang dilaksanakan terdapat yang tidak sesuai dengan kondisi dan kebutuhan. Dalam menetapkan dan melaksanakan sebuah program, lembaga hendaknya melakukan analisis, perencanaan, bentuk program, standar isi dan muatan pelatihan serta bentuk evaluasi yang akan digunakan, sehingga program tersebut tepat sasaran dan sesuai dengan kondisi dan kebutuhan lembaga. 
Adapun program peningkatan profesionalisme guru yang diselenggarakan oleh SDIT Al-Hanif, menurut pengamatan peneliti program tersebut sudah sesuai dengan kondisi dan sesuai kebutuhun. Hal itu bisa buktikan dengan melihat pada isi program tersebut. Program tashih merupakan program pemetaan kemampuan dasar seorang guru yang bertujuan untuk mengukur tingkat kemampuan dan kesiapan guru dalam aspek kemampuan membaca AlQur'an, program ini sebagai langkah awal untuk melakukan pembinaan peningkatan profesionalisme guru berikutnya melalui program tahsin.

Program tahsin merupakan program yang bertujuan untuk melakukan standarisasi bacaan guru. Dalam program ini, guru diberikan materi standarisasi pemahaman dan praktek terhadap bacaan Al-Qur'an mulai dari standarisasi makharijul huruf, sifatul huruf, harokat, mad, huruf sukun, waqaf, ghunnah, lafdzul jalalah, qolqolah, ghoribul qur'an dan tajwidul quran. Selain itu, dalam program tahsin juga diberikan standarisasi irama bacaan Al-Qur'an yang mudah dan menyenangkan. Program ini menjawab kebutuhan guru dalam aspek kemampuan membaca yang sebelumnya masih lemah. Oleh karena itu program ini sesuai dengan kondisi, kebutuhan guru dan lembaga.

Sementara program sertifikasi guru Al-Qur'an adalah program yang diselenggarakan untuk menyamakan pemahaman dan persepsi terhadap metodologi mengajar. Dalam program ini guru mendapatkan materi standarisasi metodologi pengajaran secara detail mulai dari model pengelolaan, tahapan mengajar, administrasi pembelajaran, kurikulum, target pembelajaran dan materi classroom management. Dengan program ini pula terjawablah permasalah perbedaan cara mengajar guru

Setelah dilakukan standarisasi bacaan dan metodologi pada program tashih, tahsin dan sertifikasi, dilanjutkan dengan program coach. Program coach merupakan program pendampingan awal dalam implementasi metode ummi. Dalam program coach, guru dan koordinator mendapatkan bimbingan dan pendampingan dalam memulai implementasi pembelajaran Al-Qur'an yang mencakup bagaimana menentukan koordinator, kurikulum, pembuatan jadwal, pemetaan kemampuan siswa, pengelompokan siswa, penentuan guru atau instruktur, penyiapan administrasi dan implementasi awal pembelajaran Al-Qur'an.

Program supervisi yang merupakan program penjagaan terhadap metode pembelajaran yang sudah terlaksana. Supervisi merupakan kegiatan pengawasan yang dilakukan oleh pimpinan sekolah atau orang yang sudah diberi wewenang untuk melakukan pengawasan terhadap guru atau pekerja. Supervisi dilakukan untuk mengamati dan melihat kinerja dan profesionalisme guru, apakah sudah menjalankan kegiatan sesuai dengan yang ditetapkan atau belum, juga untuk melihat kualitas dari pekerjaannya tersebut. supervisor melakukan pengamatan terhadap penguasaan kelas, tahapan mengajar, interaksi dengan siswa, cara menegur siswa, cara mengingatkan siswa, cara mengajar, memberi pemahaman terhadap materi baru, memberikan motivasi dan seterusnya.

Selain memberikan pengamatan dan penilaian terhadap cara dan tahapan mengajar, supervisor juga melihat dan menilai pilar-pilar mutu pembelajaran yang berjumlah sepuluh. Setelah melakukan pengamatan, supervisor memberikan penilaian terhadap guru yang di supervise dan pilar mutu yang dilihatnya. Berdasarkan pada hasil penilain tersebut seorang supervisor melakukan bimbingan kepada guru dan melakukan konsultasi dan memberikan pengarahan untuk perbaikan tersebut, juga berkoordinasi dengan pihak Lembaga terhadap temuan tersebut untuk diberikan arahan dan kebijakan kedepan.

Pembinaan tilawah dan pembinaan koordinator adalah program yang diselenggarakan oleh lembaga pasca pelaksanaan pembelajaran berlangsung. Program ini dilaksanakan untuk menjaga dan meningkatkan profesionalisme guru dan mutu pembelajaran Al-Qur'an di SDIT Al-Hanif. Dalam program pembinaan tilawah ini, para guru dibekali dengan pemahaman terhadap materi makhorijul huruf dan sifatul huruf secara mendalam mulai dari teori dan praktek dengan proses talaqqi dan diselenggarakan olrh pihak sekolah yang bekerjasama dengan pihak ummi. Sementara itu, program pembinaan koordinator dilaksanakan oleh pihak ummi daerah yang mengikutsertakan semua koordinator. Dalam kegiatan ini koordinator dibina dengan materi-materi manajemen pengelolaan pembelajaran Al-Qur'an yang bisa diterapkan di 
lembaganya masing-masing. Selain materi pengelolan pembelajaran di lembaga, para koordinator juga mendapakan pembinaan dalam aspek penguatan dan pendalaman tilawah.

Berdasarkan pada penjelasan di atas mengenai program tashih, tahsin, sertifikasi guru, coach, supervisi, pembinaan tilawah dan pembinaan koordinator, disimpulkan bahwa ketujuh program ini sangat bagus, perlu dilaksanakan serta sesuai dengan kondisi yang dibutuhkan oleh guru dan lembaga untuk meningkatkan kompetensi dan profesionalisme guru dalam aspek bacaan, metodologi dan implementasinya

Adapun program seminar, pelatihan dan bina pribadi islam jika diamati dengan seksama, didapati bahwa program ini tidak berkaitan langsung dengan peningkatan profesionalisme guru Al-Qur'an. Hal itu dikarenakan tujuan program seminar misalnya lebih kepada peningkatan pemahaman semata. Sementara tujuan program bina pribadi islami menekankan kepada pembentukan karakter islami guru. Dalam satu sisi memang program ini berdampak kepada pembentukan karakter dan motivasi yang nantinya diharapkan bisa memberikan pengaruh kepada peningkatan profesionalisme guru, meskipun tingkat pengaruhnya sangat minim. Jika dikaitkan dengan kondisi guru, maka program ini kurang cocok dan kurang relevan karena lebih membutuhkan program standarisasi bacaan dan metodologi pengajaran. Akan tetapi program ini memang memberikan dampak positif dalam aspek kompetensi sosial.

Berdasarkan keterangan di atas, disimpulkan bahwa program peningkatan profesionalisme guru di SDIT Al-Hanif Cilegon terdapat program yang berkaitan langsung dengan profesionalisme guru dan sudah sesuai dengan kondisi dan kebutuhan. Program yang sesuai dengan kondisi dan kebutuhan ini dalam pengamatan peneliti telah memenuhi unsurunsur analisis, perencanaan, model, pelaksanaan program dan evaluasi sehingga program ini berjalan cukup optimal dan maksimal. Adapun program yang tidak berkaitan langsung, dalam pengamatan peneliti memenuhi unsur perencanaan dan model pelaksanaan, namun tidak memenuhi unsur analisis, desain program, pengembangan dan evaluasi yaitu program seminar dan kajian selasa siang.

Dari semua program yang diselenggarakan di SDIT Al-Izzah, peneliti mengkalsifikasikan proses implementasi program peningkatan profesionalisme guru kepada beberapa bagian. Pertama, proses implementasi yang pelaksanaanya setiap pekan yaitu program pembinaan tahsin tahfizh unit, kelompok kerja guru, supervisi guru dan program bina pribadi islami. Kedua, proses implementasi program yang pelaksaannya sebulan sekali yaitu pembinaan izzati. Ketiga, proses implementasi program yang pelaksanaannya tiga bulan sekali yaitu simaan murojaah. Keempat, proses implementasi program yang pelaksanaannya setahun sekali yaitu program mukhoyyam Al-Qur'an. Kelima, proses implementasi yang pelaksanaannya menyesuaikan kondisi yaitu sertifikasi guru dan wisuda, seminar dan pelatihan dan studi banding.

Adapun pelaksanaan program peningkatan profesionalisme guru di SDIT Al-Hanif dibagi menjadi dua jenis. Pertama, program yang pelaksanaannya bekerjasama dengan pihak Ummi Foundation Surabaya yaitu program tashih, tahsin, sertifikasi guru, coach, supervisi, pembinaan tilawah dan pembinaan koordinator. Kedua, program internal yang pelaksanaannya tidak bekerjasama dengan pihak luar yaitu program kajian selasa siang dan seminar. Berdasarkan pengamatan peneliti, program yang diselenggarakan oleh internal dan bekerjasama dengan pihak Ummi Foundation Surabaya berjalan dengan baik dan menjalankan tahapan yang baik dan benar, mulai tahapan persiapan, tahapan inti dan tahapan akhir.

Secara umum proses implementasi program peningkatan guru di SDIT Al-Izzah berjalan cukup baik pada program sertifikasi guru, supervisi, kelompok kerja guru dan bina pribadi islami. Sementara itu, pada program pembinaan izzati, pembinaan tahsin, simaan, mukhoyyam Al-Qur'an, studi banding dan seminar belum berjalan dengan baik, efektif dan optimal. Adapun proses implementasi program peningkatan peofesionalisme guru di SDIT AlHanif berjalan dengan baik pada program tashih, tahsin, sertifikasi guru, coach, supervisi, 
pembinaan tilawah dan pembinaan koordinator dan program kajian selasa siang. Sementara itu, pada dan seminar belum berjalan dengan optimal

\section{Kesimpulan}

Profesionalisme guru Al-Qur'an di SDIT Al-Izzah dan Al-Hanif sudah baik dalam aspek landasan ilmu kependidikan, penyusunan program pembelajaran, pelaksanaan program pengajaran, penilaian hasil dan proses belajar mengajar, administrasi sekolah, layanan dan bimbingan konseling, self-concept, self-esteem yang baik, keyakinan guru terhadap kefektifan kemampuannya sendiri dalam membangkitkan gairah siswa dan sikap penerimaan terhadap diri sendiri dan orang lain, berkepribadian baik dan kesejahteraan guru. Sementara itu, Program peningkatan profesionalisme guru Al-Qur'an SDIT Al-Izzah adalah pembinaan izzati, pembinaan tahsin, simaan, sertifikasi guru, mukhoyyam Al-Qur'an, supervisi, kelompok kerja guru, studi banding, seminar dan bina pribadi Islami. Sementara itu, program peningkatan profesionalisme guru Al-Qur'an SDIT Al-Hanif adalah tashih, tahsin, sertifikasi guru, coach, supervisi, pembinaan tilawah, pembinaan koordinator, seminar dan kajian selasa siang.

\section{Daftar Pustaka}

Amrulah, A. K. (2015). Manajemen Peningkatan Profesionalisme Guru Di SMP Islam Terpadu Ukhuwah Banjarmasin. Prosiding Seminar Nasional PS2DM UNLAM, 1(2), 25-30.

Anggoro, S., Harmianto, S., \& Yuwono, P. D. (2018). Upaya Meningkatkan Kemampuan Pedagogik Guru Melalui Pelatihan Pembelajaran Tematik Sains Menggunakan Inquiry Learning Process Dan Science Activity Based Daily Life. JPPM (Jurnal Pengabdian Dan Pemberdayaan Masyarakat), 2(1), 29. https://doi.org/10.30595/jppm.v2i1.1844

Baharun, H. (2016). Penilaian Berbasis Kelas Pada Pembelajaran Pendidikan Agama Islam Di Madrasah. MODELING: Jurnal Program Studi PGMI, 3(2).

Darmadi, H. (2015). Tugas, Peran, Kompetensi, dan Tanggung Jawab Menjadi Guru Profesional. Edukasi: Jurnal Pendidikan, 13(2), 161-174.

Erwiyanto, M. (2019). Pendalaman Tilawah. Ummi Media Center.

Fathurrahman, F. (2018). Peningkatan Profesionalisme Guru Bahasa Melalui Supervisi $\begin{array}{lllll}\text { Pengajaran Kepala Sekolah. Jurnal Reforma, } & 7(1),\end{array}$ https://doi.org/10.30736/rfma.v7i1.38

Hamalik, O. (2006). Perencanaan Pengajaran Berdasarkan Pendekatan Sistem. Bumi Aksara.

Kunandar. (2007). Guru Profesional: Implementasi Kurikulum Tingkat Satuan. Pendidikan (KTSP) dan Sukses dalam Sertifikasi Guru. Rajagrafindo Persada.

Lubis, S. (2017). Peningkatan Profesionalisme Guru PAI Melalui Kelompok Kerja Guru (KKG). Jurnal Pendidikan Agama Islam Al-Thariqah, 2(2), 189-205. https://doi.org/10.25299/althariqah.2017.vol2(2).1045

Lukman, L., \& Ramli, R. (2016). Hubungan Antara Motivasi Kerja dan Tingkat Partisipasi Kelompok Kerja Guru Sekolah Dasar Dengan Peningkatan Profesionalisme Guru Pendidikan Agama Islam. Jurnal Istiqra', III(2), 274-286.

Mania, S. (2008). Observasi Sebagai Alat Evaluasi Dalam Dunia Pendidikan Dan Pengajaran. Lentera Pendidikan: Jurnal Ilmu Tarbiyah Dan Keguruan, 11(2), 220-233. https://doi.org/10.24252/lp.2008v11n2a7

Masruri. (2016). Sertifikasi Guru Al-Qur'an Metode Ummi. Lembaga Ummi Foundation.

Musyadad, A. (2020). Peran Kelompok kerja Guru dalam Meningkatkan Profesionalisme Guru Pendidikan Agama Islam Sekolah Dasar di Kecamatan Dlingo Bantul. Jurnal Ilmu Tarbiyah, 9(1), 139-164.

Nasution. (2003). Metode Penelitian Naturalistik Kualitatif. Tarsito.

Nasution, H. F. (2017). Urgensi Profesionalisme Guru di Pendidikan Sekolah Dasar. ARRIAYAH : Jurnal Pendidikan Dasar, 1(1), 1. https://doi.org/10.29240/jpd.v1i1.218 
Noorjannah, L. (2014). Pengembangan Profesionalisme Guru Melalui Penulisan Karya Tulis Ilmiah Bagi Guru Profesional Di SMA Negeri 1 Kauman Kabupaten Tulung agung. Jurnal Humanity, 10, 97-114.

Rahman, A. (2013). Pola Pembinaan Peningkatan Profesionalitas Guru SMK Kota Medan. Jurnal Tabularasa, 10(1).

Rumapea, P. (2005). Hubungan Kewenangan Kepala Sekolah dengan Kinerja Guru. Jurnal Ilmu Pendidikan, 12(1), 1-11.

Rusman. (2012). Model-Model Pembelajaran Mengembangkan Profesionalisme Guru. Rajagrafindo Persada.

Salmiati, S., \& Septiawansyah, R. (2019). Peranan Administrasi Pendidikan dalam Meningkatkan Profesionalisme Guru Pendidikan Agama Islam (PAI) pada MTs DDI Cilellang Kabupaten Barru. Al-Musannif, 1(1), 47-64. https://doi.org/https://doi.org/10.5281/zenodo.2735066

Sholihah, B. (2018). Evaluasi Dan Supervisi Program Pembelajaran Al-Qur'an Di Sekolah Dasar Islam Bilingual an-Nissa Semarang. Tarbawi: Jurnal Pendidikan Islam, 15(1). https://doi.org/10.34001/tarbawi.v15i1.718

Sudiati, T. (2018). Peningkatan Kinerja Guru Dalam Menetapkan Kriteria Ketuntasan Minimal Melalui Workshop. Ilmu Pendidikan: Jurnal Kajian Teori Dan Praktik Kependidikan, 3(2), 231-237.

Zubair, A. (2017). Manajemen Peningkatan Kinerja Guru. Jurnal Manager Pendidikan, 11(4), $305-311$. 